\title{
GEOPOLYMER CONCRETE- A REVIEW
}

\author{
M. I. Abdul Aleem ${ }^{1}$, P. D. Arumairaj ${ }^{2}$ \\ ${ }^{1}$ Assistant Professor (Selection Grade), Department of Civil Engineering, Sri \\ Ramakrishna Institute of Technology, Coimbatore, India. \\ ${ }^{2}$ Associate Professor in Civil Engineering, Govt. College of Technology, Coimbatore, India.
}

\begin{abstract}
Concrete is the world's most versatile, durable and reliable construction material. Next to water, concrete is the most used material, which required large quantities of Portland Cement. Ordinary Portland Cement production is the second only to the automobile as the major generator of carbon di oxide, which polluted the atmosphere. In addition to that large amount energy was also consumed for the cement production. Hence, it is inevitable to find an alternative material to the existing most expensive, most resource consuming Portland Cement. Geopolymer concrete is an innovative construction material which shall be produced by the chemical action of inorganic molecules. Fly Ash, a by-product of coal obtained from the thermal power plant is plenty available worldwide. Flyash is rich in silica and alumina reacted with alkaline solution produced aluminosilicate gel that acted as the binding material for the concrete. It is an excellent alternative construction material to the existing plain cement concrete. Geopolymer concrete shall be produced without using any amount of ordinary Portland cement. This paper briefly reviews the constituents of geopolymer concrete, its strength and potential applications.
\end{abstract}

KEYWORDS: Geopolymer Concrete, Fly Ash, Strength, Curing, Applications.

\section{INTRODUCTION}

The name geopolymer was formed by a French Professor Davidovits in 1978 to represent a broad range of materials characterized by networks of inorganic molecules (Geopolymer Institute 2010) ), $^{1,}$ \&3. The geopolymers depend on thermally activated natural materials like Meta kaolinite or industrial byproducts like fly ash or slag to provide a source of silicon $(\mathrm{Si})$ and aluminum $(\mathrm{Al})$. These Silicon and Aluminium is dissolved in an alkaline activating solution and subsequently polymerizes into molecular chains and become the binder.

Professor B. Vijaya Rangan (2008), Curtin University, Australia, stated that, "the polymerization process involves a substantially fast chemical reaction under alkaline conditions on silicon-aluminum minerals that results in a three-dimensional polymeric chain and ring structure...." ${ }^{4}$ The ultimate structure of the geopolymer depends largely on the ratio of $\mathrm{Si}$ to $\mathrm{Al}(\mathrm{Si}: \mathrm{Al})$, with the materials most often considered for use in transportation infrastructure typically having an Si:Al between 2 and $3.5^{5}$ $\& 6$.

The reaction of Fly Ash with an aqueous solution containing Sodium Hydroxide and Sodium Silicate in their mass ratio, results in a material with three dimensional polymeric chain and ring structure consisting of Si-O-Al-O bonds?

The schematic formation of geopolymer material can be shown as described by Equations (A) and (B).

$\mathrm{n}\left(\mathrm{Si}_{2} \mathrm{O}_{5}, \mathrm{Al}_{2} \mathrm{O}_{2}\right)+2 \mathrm{nSiO}_{2}+4 \mathrm{nH}_{2} \mathrm{O}+\mathrm{NaOH}$ or $\mathrm{KOH} \rightarrow \mathrm{Na}^{+}{ }_{n} \mathrm{~K}^{+}+\mathrm{n}(\mathrm{OH})_{\mathrm{a}}-\mathrm{Si}-\mathrm{O}-\mathrm{Al}^{-}-\mathrm{O}-\mathrm{Si}-(\mathrm{OH})_{3}$

(Si-Al materials)

(Geopolymer precursor) 


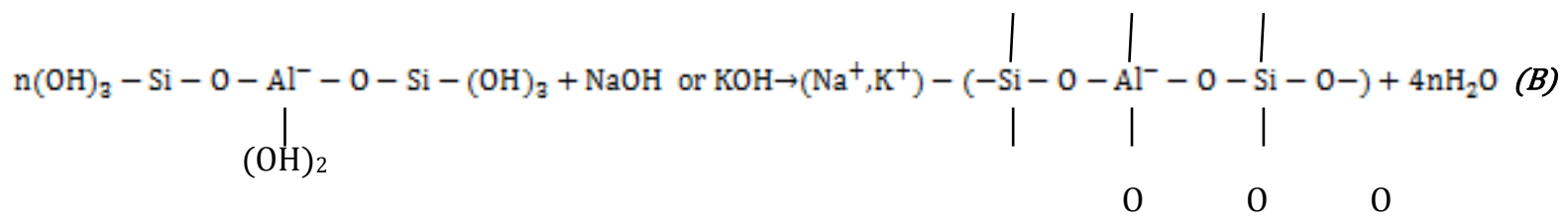

(Geopolymer backbone)

Water is not involved in the chemical reaction of Geopolymer concrete and instead water is expelled during curing and subsequent drying. This is in contrast to the hydration reactions that occur when Portland cement is mixed with water, which produce the primary hydration products calcium silicate hydrate and calcium hydroxide. This difference has a significant impact on the mechanical and chemical properties of the resulting geopolymer concrete, and also renders it more resistant to heat, water ingress, alkali-aggregate reactivity, and other types of chemical attack ${ }^{3 \& 5}$.

In the case of geopolymers made from fly ash, the role of calcium in these systems is very important, because its presence can result in flash setting and therefore must be carefully controlled ${ }^{5}$. The source material is mixed with an activating solution that provides the alkalinity (sodium hydroxide or potassium hydroxide are often used) needed to liberate the $\mathrm{Si}$ and $\mathrm{Al}$ and possibly with an additional source of silica (sodium silicate is most commonly used).

The temperature during curing is very important, and depending upon the source materials and activating solution, heat often must be applied to facilitate polymerization, although some systems have been developed that are designed to be cured at room temperature ${ }^{2 \& 3}$.

The necessity of Geopolymer Concrete, the Constituents, Properties, Applications and Limitations are discussed in detail in this paper.

\section{NeCESSITY OF GEOPOLYMER CONCRETE}

Construction is one of the fast growing fields worldwide. As per the present world statistics, every year around 260,00,00,000 Tons of Cement is required. This quantity will be increased by $25 \%$ within a span of another 10 years. Since the Lime stone is the main source material for the ordinary Portland cement an acute shortage of limestone may come after 25 to 50 years. More over while producing one ton of cement, approximately one ton of carbon di oxide will be emitted to the atmosphere, which is a major threat for the environment. In addition to the above huge quantity of energy is also required for the production of cement. Hence it is most essential to find an alternative binder.

The Cement production generated carbon di oxide, which pollutes the atmosphere. The Thermal Industry produces a waste called flyash which is simply dumped on the earth, occupies larges areas. The waste water from the Chemical Industries is discharged into the ground which contaminates ground water. By producing Geopolymer Concrete all the above mentioned issues shall be solved by rearranging them.

Waste Fly Ash from Thermal Industry + Waste water from Chemical Refineries = Geo polymer concrete. Since Geopolymer concrete doesn't use any cement, the production of cement shall be reduced and hence the pollution of atmosphere by the emission of carbon di oxide shall also be minimized.

\section{CONSTITUENTS OF GeOPOLYMER CONCRETE}

The following are the constituents of Geopolymer concrete

$>$ Fly Ash- rich in Silica and Aluminium

$>$ Sodium Hydroxide or Potassium Hydroxide

$>$ Sodium Silicate or Potassium Silicate

\section{Properties of GeOPOLYMer ConCRETE}

The superior properties of Geopolymer concrete, based on Prof. B. Vijaya Rangan and Hardijito, are 
$>$ sets at room temperature

$>$ non toxic, bleed free

$>$ long working life before stiffening

$>$ impermeable

$>$ higher resistance to heat and resist all inorganic solvents

$>$ higher compressive strength

Compressive strength of Geopolymer concrete is very high compared to the ordinary Portland cement concrete. Geopolymer concrete also showed very high early strength. The compressive strength of Geopolymer concrete is about 1.5 times more than that of the compressive strength with the ordinary Portland cement concrete, for the same mix.

Similarly the Geopolymer Concrete showed good workability as of the ordinary Portland Cement Concrete.

\section{Applications}

In the short term, there is large potential for geopolymer concrete applications for bridges, such as precast structural elements and decks as well as structural retrofits using geopolymer-fiber composites. Geopolymer technology is most advanced in precast applications due to the relative ease in handling sensitive materials (e.g., high-alkali activating solutions) and the need for a controlled high-temperature curing environment required for many current geopolymer. Other potential nearterm applications are precast pavers $\&$ slabs for paving, bricks and precast pipes.

\section{LIMITATIONS}

The followings are the limitations

$>$ Bringing the base material fly ash to the required location

$>$ High cost for the alkaline solution

$>$ Safety risk associated with the high alkalinity of the activating solution.

$>$ Practical difficulties in applying Steam curing / high temperature curing process

Considerable research is ongoing to develop geopolymer systems that address these technical hurdles.

\section{RESUlTS \& DiscuSSION}

Joseph Davidovits found that Flyash reacted with alkaline solution and formed a binding material. Hardijito \& Rangan observed that higher concentration of sodium hydroxide (molar) resulted higher compressive strength and higher the ratio of sodium silicate-to-sodium hydroxide liquid ratio by mass, showed higher compressive strength of geopolymer concrete. They also found that the increased in curing temperature in the range of 30 to $90{ }^{\circ} \mathrm{C}$ increased the compressive strength of geopolymer concrete and longer curing time also increased the compressive strength. They handled the geopolymer concrete up to120 minutes without any sign of setting and without any degradation in the compressive strength, resulted very little drying shrinkage and low creep.

Suresh Thokchom etal reported that the Geopolymer mortar specimens manufactured from fly ash with alkaline activators were structurally intact and did not show any recognizable change in colour after 18 weeks exposure in $10 \%$ sulfuric acid solution and the Geopolymer Concrete was high resistance against sulfuric acid.

D. Bondar etal indicated that the strength of geopolymer concrete decreased as the ratio of water to geopolymer solids by mass increased. Anuar etal revealed that the concentration (in term of molarity) of $\mathrm{NaOH}$ influenced the strength characteristic of geopolymer concrete. S. Vaidya etal examined that uniform temperature was developed throughout the mass and Elastic Modulus and Poission's ratio were within the acceptable limits.

Raijiwala etal noticed that the Compressive strength of GPC increased over controlled concrete by 1.5 times (M-25 achieves M-45), Split Tensile Strength of GPC increased over controlled concrete by 1.45 times and Flexural Strength of GPC increased over controlled concrete by 1.6 times. Muhd 
Fadhil Nuruddin etal recommended thatcast in-situ application in Geopoymer concrete is a viable one. Douglas etal successfully used Geopolymer Concrete in waste stabilization.Geopolymer Concrete immobilized chemical toxins and reduced leachate level concentrations.

\section{RELATED WORKS}

Since there is demand for natural sand, the fine aggregate shall be replaced partially by quarry dust. Quarry dust is having high content of Silica, which may increase the compressive strength of Geopolymer Concrete by partial replacement of quarry dust. Different concentrations of Sodium Hydroxide solution $(8 \mathrm{M}, 10 \mathrm{M}, 12 \mathrm{M}, 14 \mathrm{M} \& 16 \mathrm{M})$ shall be used and the characteristics shall be studied.

Similarly the different curing methods shall also be studied. Hot air curing, Steam curing, Sun curing and ambient curing shall be studied for the above mentioned different Molar ratios of Sodium Hydroxide solutions.

In order to study the use of Geopolymer Concrete as of normal concrete, different structural elements like Plain Cement Concrete Beam, Reinforced Cement Concrete Beam, Reinforced Concrete Columns, Reinforced Beam Column joints shall be cast for the above mentioned concentrations of Sodium Hydroxide solution and curing conditions and tested. The characteristics of geopolymer concrete shall be studied and based on the test results use of Geopolymer Concrete in place of ordinary Portland cement concrete shall be recommended.

\section{CONCLUSION}

User-friendly geopolymer concrete can be used under conditions similar to those suitable for ordinary portland cement concrete. These constituents of Geopolymer Concrete shall be capable of being mixed with a relatively low-alkali activating solution and must be curable in a reasonable time under ambient conditions. The production of versatile, cost-effective geopolymer concrete can be mixed and hardened essentially like portland cement. Geopolymer Concrete shall be used in repairs and rehabilitation works.

Due to the high early strength Geopolymer Concrete shall be effectively used in the precast industries, so that huge production is possible in short duration and the breakage during transportation shall also be minimized. The Geopolymer Concrete shall be effectively used for the beam column junction of a reinforced concrete structure. Geopolymer Concrete shall also be used in the Infrastructure works. In addition to that the Flyash shall be effectively used and hence no landfills are required to dump the flyash.

The government can make necessary steps to extract sodium hydroxide and sodium silicate solution from the waste materials of chemical industries, so that the cost of alkaline solutions required for the geopolymer concrete shall be reduced.

\section{REFERENCES}

[1]. Davidovits, J. 1984. "Pyramids of Egypt Made of Man- Made Stone, Myth or Fact?" Symposium on Archaeometry 1984. Smithsonian Institution, Washington, DC.

[2]. Davidovits, J. 2008. Geopolymer Chemistry and Applications. Institut Géopolymère, Saint-Quentin, France.

[3]. Geopolymer Institute. 2010. What Is a Geopolymer? Introduction. Institut Géopolymère, SaintQuentin, France. Accessed on January 29, 2010, at http://www.geopolymer.org/science/introduction.

[4]. Hardjito, D., S. Wallah, D. M. J. Sumajouw, and B. V. Rangan. 2004. "On the Development of Fly Ash- Based Geopolymer Concrete.” ACI Materials Journal, vol. 101, no. 6.

[5]. Rangan, B. V.. "Low-Calcium, Fly-Ash-Based Geopolymer Concrete." Concrete Construction Engineering Handbook. Taylor and Francis Group, Boca Raton, FL, 2008.

[6]. Lloyd, N., and V. Rangan. 2009. "Geopolymer Concrete-Sustainable Cementless Concrete." ACI Special Publication SP-261, 10th ACI International Conference on Recent Advances in Concrete Technology and Sustainability Issues. American Concrete Institute, Farmington Hills, MI. 
[7]. Recent Research Geopolymer Concrete- Nguyen Van Chanh Bui Dang Trung, Dang Van Tuan during the $3^{\text {rd }}$ ACF International Conference-ACF/VCA 2008.

[8]. Suresh Thokchom, Partha Ghosh and Somnath Ghos - Resistance of Fly Ash based Geopolymer Mortars in Sulfuric Acid- ARPN Journal of Engineering and Applied SciencesVOL. 4, NO. 1, FEBRUARY 2009.

[9]. D. Bondar(a), C. J. Lynsdale(b), N. B. Milestone(c), N. Hassani(d), and A. A. Ramezanianpour Engineering Properties of Alkali Activated Natural Pozzolan Concrete -Second International Conference, University of Wisconsin,June2010.

[10]. Anuar K.A, Ridzuan A.R.M., Ismail S., Universiti Teknologi MARA 40450 Shah Alam, Selangor, Malaysia, Strength Characteristic of Geopolymer Concrete - International Journal of Civil \& Environmental Engineering, Vol: 11 No: 01 February2011.

[11]. S. Vaidya and etal- Experimental evaluation of Self cure Geopolymer concrete for mass pour application - World Coal Ash Conference,2011.

[12]. Raijiwala D.B.1 Patil H. S - Geopolymer Concrete- a Concrete of next decade, Journal of Engineering Research and Studies., March 2011.

[13]. Muhd Fadhil Nuruddin, Andri Kusbiantoro, Sobia Qazi, Nasir Shafiq- Compressive Strength and Interfacial Transition Zone Characteristic of Geopolymer Concrete with Different Cast In-Situ Curing Conditions, World Academy of Science, Engineering and Technology, 2011.

[14]. Douglas C. Comrie, John H. Paterson \& Douglas J. Ritcey, D. Code Consulting Ltd, Boulevard East, Mississauga, Ontario - Applications of geopolymer technology to waste stabilization.

\section{Biography}

M. I. Abdul Aleem, Assistant Professor(Selection Grade), Department of Civil Engineering, Sri Ramakrishna Institute of Technology, Coimbatore -10, India. He has obtained his Bachelors Degree in Civil Engineering from Govt. College of Technology, Coimbatore in the year 1986, Masters Degree in Structural Engineering from PSG College of Technology, Coimbatore in the year 1991 and at present he is pursuing his Doctorate Degree under the Anna University of Technology, Coimbatore, India. He is the Member of Institution of Engineers (India), Life Member in Indian Society for Technical Education and Associate Member in Institution of Valuers. He has 17 years of field experience and 8 years of Teaching experience. He has presented many papers in National Seminars and Conferences and has attended International Conferences. He has delivered many Guest Lectures in Reputed Engineering Colleges and Engineering Organisations. He has conducted many Seminars, Conferences and Staff Development Programmes by getting sponsorship from Government Agencies. He has worked as a Project Geotechnical Engineer in the Public Works Department of Brunei Darussalam and also as a Senior Engineer in a Consulting Firm called Jurusy Perunding, in the same country. He has effectively designed and executed multi million dollar projects.

P. D. Arumairaj, Associate Professor in Civil Engineering, Govt. College of Technology, Coimbatore -13, India. He has obtained his Bachelors Degree in Civil Engineering from Regional Engineering College, Trichy in the year 1983, Masters Degree in Geotechnical Engineering from Govt. College College of Technology, Coimbatore in the year 1989 and Doctorate Degree in the year 2006, under Bharathiyar University, Coimbatore. He has 28 years of Teaching experience. He has published many papers in National and International Journals.

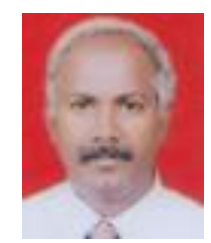
He has guided 36 M.E. Project Thesis and at present guiding 4 Ph.D Research Scholars. He has been the Resource Person for various Seminars and Conferences conducted in many Engineering Colleges and has delivered many lectures in topics of recent developments \& issues in Civil Engineering. He is also leading the Consulting Team of the Govt. College of Technology, Coimbatore for the Geotechnical works. He has effectively designed and executed many slope protection works and foundation systems. 